\title{
Conohyus simorrensis (Lartet, 1851) (Suidae, Mammalia) from the Middle Miocene of Carpetana (Madrid, Spain)
}

\section{Martin PICKFORD}

Département Histoire de la Terre, and UMR 7207 (CR2P) du CNRS, 8 rue Buffon, 75005, Paris, France; pickford@mnhn.fr

Pickford, M. 2013. Conohyus simorrensis (Lartet, 1851) (Suidae, Mammalia) from the Middle Miocene of Carpetana (Madrid, Spain). [Conohyus simorrensis (Lartet, 1851) (Suidae, Mammalia) del Mioceno Medio de Carpetana (Madrid, España)]. Spanish Journal of Palaeontology, 28 (1), 91-102.

\begin{abstract}
Fossil suid remains excavated from Middle Miocene deposits at Carpetana, Madrid, comprise mandibles and isolated teeth of the tetraconodont suid, Conohyus simorrensis (Lartet, 1851). The Carpetana mandible is the most complete specimen known for the genus and throws a great deal of light on the morphology of the anterior dentition. Heavy wear on all the teeth, including deciduous ones in the sample, indicates a diet of abrasive or durable food items such as nuts.
\end{abstract}

Keywords: Tetraconodontinae, taxonomy, palaeoecology, revision, dento-gnathic.

\section{RESUMEN}

Los restos fósiles de suidos del Mioceno medio extraídos del yacimiento de Carpetana, Madrid, incluyen mandíbulas y dientes aislados del suido tetraconodóntido, Conohyus simorrensis (Lartet, 1851). La mandíbula de Carpetana es el espécimen más completo conocido y proporciona una valiosa información sobre la morfología de la dentición anterior. Un intenso desgaste en todos los dientes, incluso en los de leche, indica una dieta a base de comida abrasiva y dura, como nueces.

Palabras clave: Tetraconodontinae, taxonomía, paleoecología, revisión, dento-maxilar. 


\section{INTRODUCTION}

Rescue excavations of the Carpetana fossil level were undertaken in 2008 when a richly fossiliferous sediment deposit was intersected during the construction of the Carpetana Metro, Madrid. Among the fossils collected are important, relatively complete, mandibular specimens of Conohyus simorrensis, which throw a great deal of light on this enigmatic taxon. Hitherto the subject of a great deal of uncertainty because the original hypodigm of the taxon was thought to have been lost, the genus and species have been redefined following the rediscovery of Lartet's (1851) collections in the Natural History Museum, Toulouse (Pickford \& Laurent, in press).

Specimens labelled Sus simorrensis in the Toulouse collection include remains of three suid species, Listriodon splendens (upper and lower canines), Conohyus simorrensis (mandible, maxilla and isolated teeth) and Conohyus goeriachensis (maxillae, mandibles and isolated teeth). By the time of Stehlin's (1899-1900) monograph, the Lartet collection had already been "lost", so his concept of Conohyus simorrensis was based mainly on mandibles from Le Fousseret, France, which conform in morphology to the recently nominated lectotype (Pickford \& Laurent, in press) but which are slightly larger than the fossils from Villefranche d'Astarac, the type locality. The Carpetana fossils yield additional information about Conohyus simorrensis including details of anterior premolars, canine and incisor morphology and the shape of the symphysis, none of which can be observed in the lectotype which is a mandible broken at the level of the $\mathrm{p} / 2$.

\section{MATERIAL AND METHODS}

The fossils described herein are housed in the Museo Nacional de Ciencias Naturales, Madrid (MNCN). They are compared with tetracondonts from Europe and Asia (Fig. 1) housed in many museums, comprising over 2,000 dental specimens (author's personal data base), but especially with fossils from the type locality, Villefranche d'Astarac, housed in the Natural History Museum, Toulouse.

Measurements are in $\mathrm{mm}$. Dental nomenclature is based on Hünermann (1968), Pickford (1988) and Van der Made (1998). Upper teeth are abbreviated in capital letters and lower teeth in lower case letters $(\mathrm{C}, \mathrm{c}$ - canines, $\mathrm{I}, \mathrm{i}$ - incisors, $\mathrm{M}, \mathrm{m}$ - molars, $\mathrm{P}, \mathrm{p}$ - premolars). The meristic position is above the slash for upper teeth (M3/ - upper third molar) and below the slash for lower teeth $(\mathrm{p} / 3$ lower third premolar), the slash representing the occlusal plane.

\section{SYSTEMATIC DESCRIPTION}

Family Suidae Gray, 1821

Subfamily Tetraconodontinae Lydekker, 1876

Genus Conohyus Pilgrim, 1925

Sus simorrensis Lartet, 1851, by original designation.

Conohyus simorrensis (Lartet, 1851)

Diagnosis. Species of Conohyus in which the molar row measures ca $60 \mathrm{~mm}$ and the $\mathrm{p} / 2-\mathrm{p} / 4$ row measures ca $56 \mathrm{~mm}$. Anterior premolars somewhat trenchant, distal root of $\mathrm{m} / 3$ slightly buccally tilted. Lower male canine possesses a ridge of cementum on the distal enamel-free surface of the crown (diagnosis from Pickford \& Laurent, in press).

\section{Synonymy}

partim Sus simorrensis Lartet, 1851

partim Sus (?) Doati Lartet, 1851

Sus abnormis Kaup, 1859

partim Hyotherium simorrense (Lartet, 1851): Stehlin, 1899-1900

Hyotherium soemmeringi matritensis Golpe-Posse, 1972

Conohyus melendezi Golpe-Posse, 1972

Conohyus simorrensis (Lartet, 1851): Van der Made \& Morales, 2003

Non Conohyus simorrensis (Lartet, 1851): Van der Made \& Salesa, 2004 = Conohyus goeriachensis Van der Made, 1989

Age. Middle Miocene, base of Zone MN 6. The species Conohyus simorrensis has been reported in European localities correlated to biozones MN5 to MN8, but the material from MN 5 is smaller than $C$. simorrensis. Hünermann (1999) thought that the type locality was Simorre, dated to MN7 but the lectotype is from Villefranche d'Astarac (Pickford \& Laurent, in press). According to Pickford \& Morales (2003) and/or Fortelius et al. (1996), C. simorrensis is also recorded in Mala Miliva (Turkey, MN5), Elgg (Switzerland, MN5), Göriach (Austria, MN6), Pasalar (Turkey, MN6), Kleineisenbach (Germany, MN8), but most of these records pertain to different species (work in press) (Fig. 1).

Description. The tetraconodont mandible from Carpetana (MNCN 08.17.7180; Figs 2-5; Table 1) is one of the most complete known for European Tetraconodontinae, but it has been compressed, and the bone is broken into pieces which have been slightly displaced relative to each other. The teeth are no longer in their correct positions, but have retained their correct order in the mandible. The $\mathrm{i} / 3 \mathrm{~s}$ and the left $\mathrm{p} / 1$ are missing, but the central incisors, 


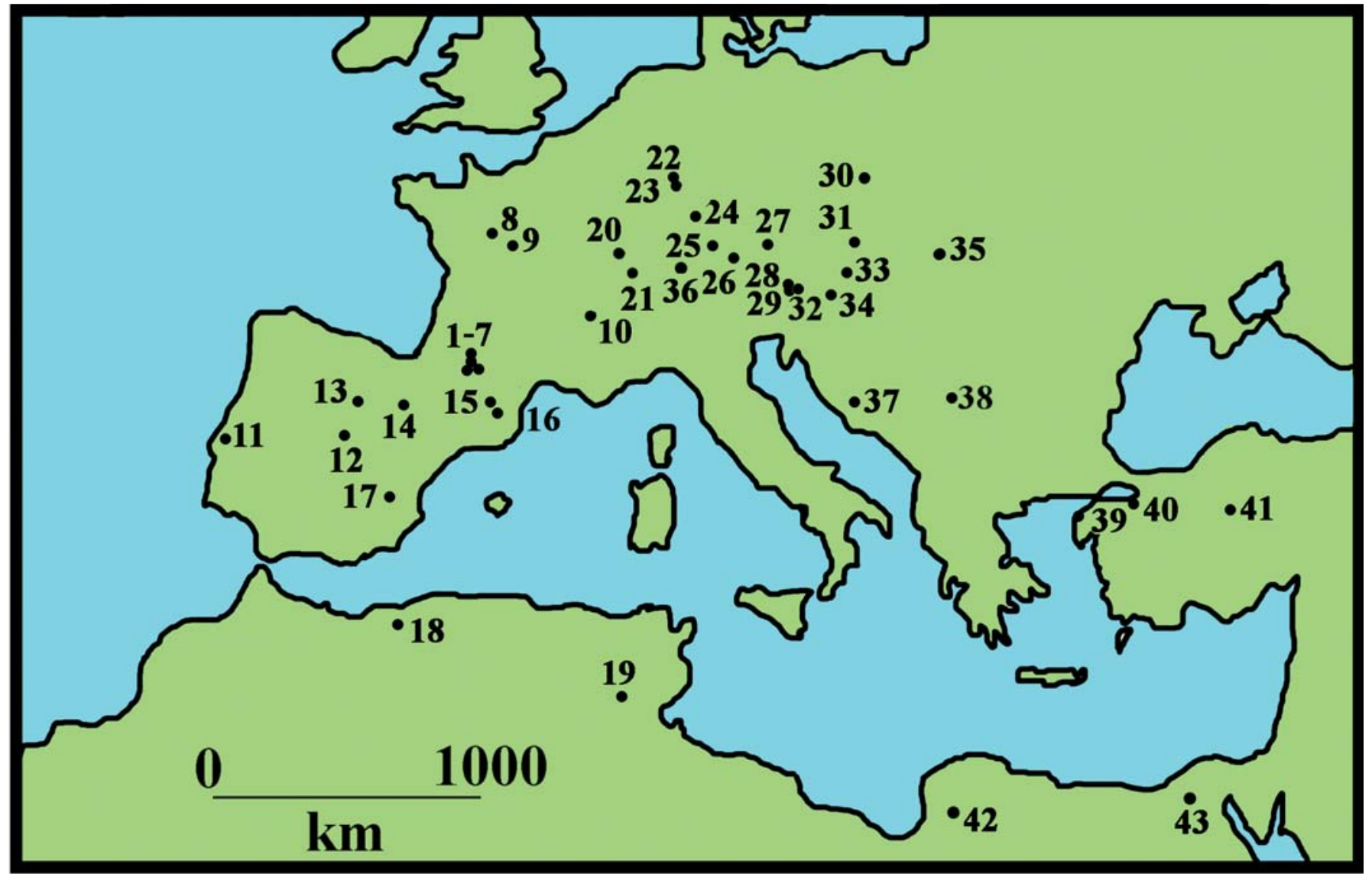

Figure 1. Location of selected European and North African tetraconodont localities. Carpetana is in Madrid, $n^{\circ} 12.1$ ) Malartic, 2) Sansan, 3) Simorre, 4) Villefranche d'Astarac, 5) Bonnefond, 6) Le Fousseret, 7) Saint Gaudens (Valentine), 8) Lublé, Hommes, 9) Channay, Pontlevoy, 10) La Grive-Saint-Alban, 11) Fonte do Pinheiro, Pero Filho, Azambujeira, 12) Carpetana, Puente de Vallecas, Alhambra, Somosaguas, 13) Montejo de la Vega, 14) El Buste, La Ciesma, 15) St Quirze, 16) Can Llobateres, Can Ponsic, Santiga, 17) Mira, 18) Bou Hanifia (Dublineau), 19) Beglia, 20) Charmoille, 21) La Chaux-deFonds, 22) Gau-Weinheim (Wiesberg), 23) Esselborn, Eppelsheim, 24) Steinheim, 25) Breitenbrunn, 26) Urlau, Tutzing, 27) Pischelsberg, 28) Göriach, 29) Au, 30) Przeworno, 31) Klein Hadersdorf, Atzelsdorf, 32) Rosenthal 33) Neudorf, 34) Pitten, 35) Rudabanya, 36) Elgg, 37) Lucane, 38) Mala Miliva, 39) Nuri Yamut, 40) Pasalar, 41) Bâlâ, 42) Sahabi, 43) Wadi Natrun.

both canines, the complete right cheek tooth row, and the left cheek tooth row minus the $\mathrm{p} / 1$ are preserved.

The root of the ascending ramus starts far back, opposite the middle of $\mathrm{m} / 3$ and thus, in lateral view, does not hide much of the talonid of $\mathrm{m} / 3$.

In the right mandible there is a mental foramen beneath the centre of the $\mathrm{p} / 2$, and in the left mandible the posterior mental foramen is preserved beneath the anterior root of the $\mathrm{p} / 4$. The sub-lingual fossa is deep, but badly damaged. The symphysis extends back as far as the front root of $\mathrm{p} / 3$. It is $68 \mathrm{~mm}$ long measured along the dorsal surface.

The central and second incisors are robust teeth but are so worn that few details of morphology remain. It is possible to infer the former presence of strong lingual central ribs. The $\mathrm{i} / 3 \mathrm{~s}$ are represented by parts of their alveoli, which indicate that they were small teeth. The canine is hypselodont and scrofic in section, evidently a male individual. The buccal surface has a prominent longitudinal groove, the lingual surface a very shallow one. The posterior, enamel-free surface, has a longitudinal ridge of cementum, a highly unusual feature in suids, but also present in a specimen from Bonnefond, France, here attributed to Conohyus doati (Hyotherium simorrense in Stehlin, 1899-1900; pl. 7, fig. 12). The canine is steeply inserted in the jaw, but is not vertical, the apex lying slightly lateral to the tooth row.

The $p / 1$ is a two-rooted tooth, but the two roots are confluent throughout their length. It shows no signs of wear. The main cusp is in an anterior position such that the mesial cristid is shorter and steeper than the posterior cristid. The mesial cristid terminates in a low, almost rudimentary, mesial accessory cusplet. The distal cristid in contrast bifurcates about half way towards the distal margin of the tooth, and the posterior part of the crown 
Table 1. Measurements (in $\mathrm{mm}$ ) of the teeth of Conohyus simorrensis (Lartet, 1851) from Carpetana, Madrid, Spain (lt - left, rt - right).

\begin{tabular}{llll}
\hline Catalogue N & Tooth & Length & Breadth \\
\hline MNCN 08.17.7180 6-148 & $\mathrm{c} / 1 \mathrm{lt}$ & 17.2 & 15.0 \\
MNCN 08.17.7180 6-148 & $\mathrm{i} / 1 \mathrm{rt}$ & 6.7 & 10.2 \\
MNCN 08.17.10904 A & $\mathrm{i} / 2 \mathrm{lt}$ & 8.2 & 12.1 \\
MNCN 08.17.7180 6-148 & $\mathrm{i} / 2 \mathrm{rt}$ & 7.0 & 12.3 \\
MNCN 08.17.9702 & $\mathrm{I} / \mathrm{rt}$ & 9.4 & 12.4 \\
MNCN 08.17.10904 A & $\mathrm{m} / 1 \mathrm{lt}$ & 17.0 & 13.1 \\
MNCN 08.17.7180 6-148 & $\mathrm{m} / 1 \mathrm{lt}$ & 17.0 & 14.0 \\
MNCN 08.17.7180 6-148 & $\mathrm{m} / 1 \mathrm{rt}$ & 16.8 & 13.7 \\
MNCN 08.17.10904 A & $\mathrm{m} / 2 \mathrm{lt}$ & 19.4 & 14.3 \\
MNCN 08.17.7180 6-148 & $\mathrm{m} / 2 \mathrm{lt}$ & 19.0 & 16.0 \\
MNCN 08.17.7180 6-148 & $\mathrm{m} / 2 \mathrm{rt}$ & 18.7 & 14.8 \\
MNCN 08.17.10904 A & $\mathrm{m} / 3 \mathrm{lt}$ & 26.2 & 15.6 \\
MNCN 08.17.7180 6-148 & $\mathrm{m} / 3 \mathrm{lt}$ & 26.2 & 16.4 \\
MNCN 08.17.7180 6-148 & $\mathrm{m} / 3 \mathrm{rt}$ & 26.0 & 16.3 \\
MNCN 08.17.7180 6-148 & $\mathrm{p} / 1 \mathrm{rt}$ & 13.3 & 6.0 \\
MNCN 08.17.7180 6-148 & $\mathrm{p} / 2 \mathrm{lt}$ & 18.1 & 8.4 \\
MNCN 08.17.7180 6-148 & $\mathrm{p} / 2 \mathrm{rt}$ & 17.6 & 8.0 \\
MNCN 08.17.7180 6-148 & $\mathrm{p} / 3 \mathrm{lt}$ & 22.5 & 15.7 \\
MNCN 08.17.7180 6-148 & $\mathrm{p} / 3 \mathrm{rt}$ & 22.1 & 14.8 \\
MNCN 08.17.10904 B & $\mathrm{p} / 4 \mathrm{lt}$ & 20.2 & 14.0 \\
MNCN 08.17.7180 6-148 & $\mathrm{p} / 4 \mathrm{lt}$ & 17.4 & 15.0 \\
MNCN 08.17.7180 6-148 & $\mathrm{p} / 4 \mathrm{rt}$ & 17.0 & 14.7 \\
\hline
\end{tabular}

is swollen lingually, but not to the extent of forming a separate cusplet.

The $\mathrm{p} / 2$ is a lightly worn, two-rooted tooth in which the roots are not greatly separated from each other, both of them inclined anteriorly. The main cusp is quite sectorial and its apex lies above the gap between the two roots. The mesial cristid terminates at a low swelling at the front of the tooth, but does not form a distinct cusplet. The posterior cristid descends towards the cervix distally but about half way down it swings buccally, terminating at a low swelling. The lingual side of the back of the tooth is swollen, but not forming a separate cusplet.

The $p / 3$ is in medium wear. It sits on two stout roots which are inclined anteriorly to a slight extent. This tooth is considerably larger than the $\mathrm{p} / 2$. It shows wrinkled enamel. The main cusp is located above the gap between the two roots. The mesial cristid is steep and terminates in a mesial cusplet from which cingular folds run a short way buccally and lingually. There is a distinct posterior accessory cusplet about half the height of the crown from which cingular folds emanate lingually and buccally. The buccal side of the tooth is more swollen than the lingual side, especially in the rear half of the crown. The enamel extends further rootwards buccally than lingually.

The $\mathrm{p} / 4$ is heavily worn, but it is possible to discern that the mesial cristid ended anteriorly at a distinct cusplet from which cingular folds run buccally and lingually. The posterior accessory cusplet is large and also gives rise to buccal and lingual cingular folds. The buccal half of the tooth is more swollen than the lingual half and the enamel extends further towards the roots buccally than lingually. The roots are stout and are inclined slightly anteriorly.

The first and second molars are deeply worn, retaining no useful information about cusp morphology. The $m / 3$ is also heavily worn with dentine lakes exposed on the four main cusps and the median accessory cusplet. All traces of Fürchen have been removed by wear. The talonid of the $\mathrm{m} / 3$ is short, comprised of a main cusp slightly to the buccal side of the midline of the crown, and it is accompanied by cingular cusplets that lie either side of the hypoconulid. The buccal and lingual ends of the median transverse valley are unencumbered by cusplets.

A second mandible fragment from Carpetana (MNCN 08.17.10904; Fig. 6) contains the three molars in a less worn condition than the more complete jaw described above. The root of the ascending ramus of the jaw takes off at about the middle of the $\mathrm{m} / 3$. The sub-lingual fossa is deep.

The $m / 1$ is deeply worn to the stage of producing two large dentine lakes surrounded by enamel. The $m / 2$ shows sub-circular dentine lakes at the tips of the four main cusps and the three midline cusplets. Small remnants of the Fürchen are preserved on the rear of the mesial cusp pair, but have been eradicated elsewhere on the crown. The $\mathrm{m} / 3$ is moderately worn but without dentine showing on any of the cusps. The talonid cusp is slightly to the buccal side of the midline, and is accompanied by large cingular cusplets either side of the hypoconulid. The buccal cingulum extends weakly along the buccal side of the crown, forming low beads in the end of the median transverse valley and behind the hypoconid. The distal root of the $\mathrm{m} / 3$ slants buccally to some degree, but much less than is the case in Conohyus steinheimensis from Steinheim, Germany. The posterior roots of the $\mathrm{p} / 4$ are partly preserved and show that they were well separated from each other, meaning that the tooth had three distinct roots.

Associated with this jaw is an isolated $\mathrm{p} / 3$ in light wear (MNCN 08.17.7180.6-148; Fig. 6). It shows a distal root that is 8 -shaped in section with two pulp cavities, but not separated into distinct roots. The mesial cristid has a beaded edge, and the mesial cusplet is relatively small with buccal and lingual cingular folds. The distal accessory cusplet is about half the height of the crown, is buccolingually broad with cingular folds on both sides. The 

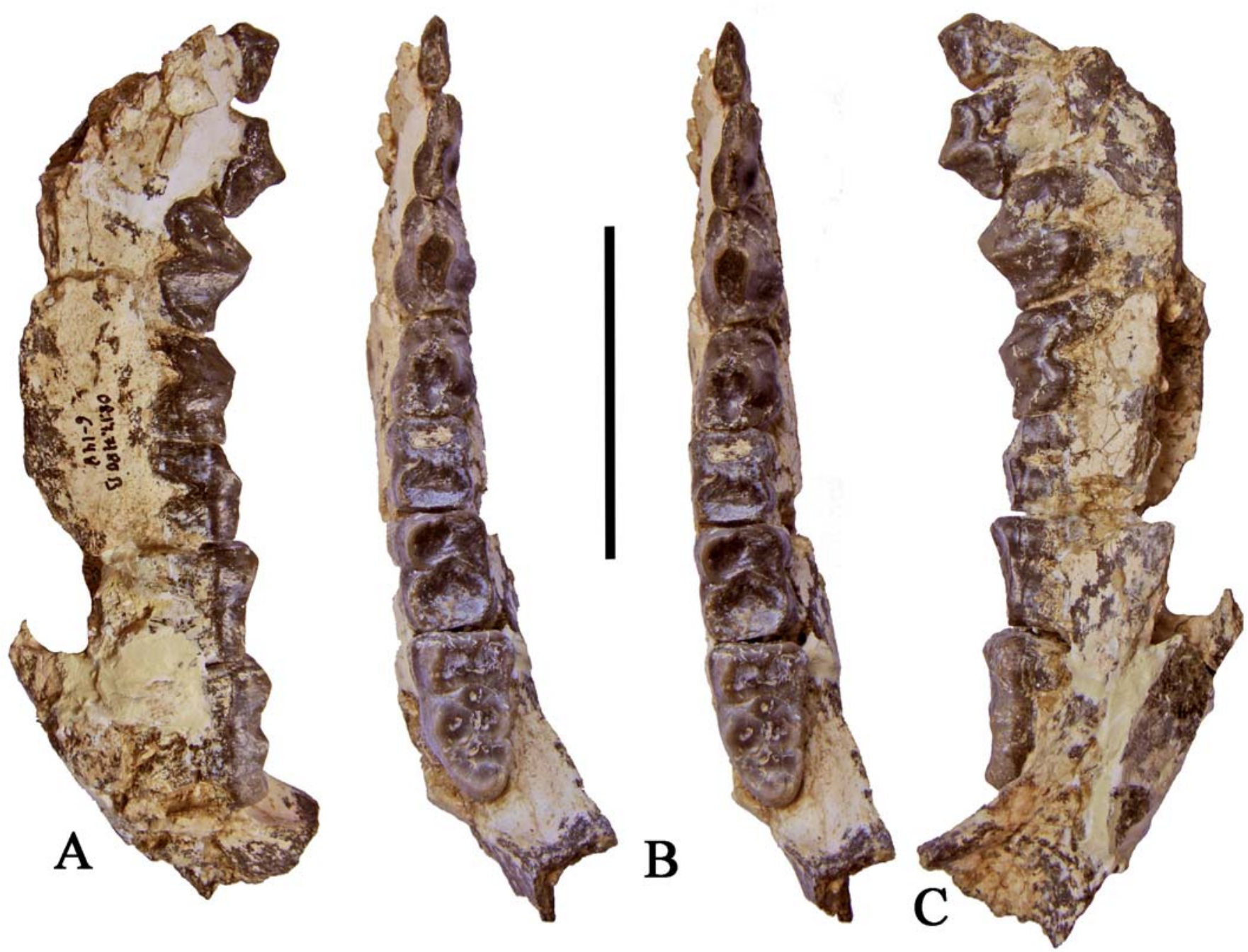

Figure 2. Conohyus simorrensis from Carpetana (MN 6), Madrid. MNCN 08.17.7180 right mandible containing p/1-m/3. A) lingual, B) stereo occlusal, and C) buccal views (scale: $5 \mathrm{~cm}$ ).

buccal side of the tooth is more swollen than the lingual side, and the enamel extends further rootwards buccally than lingually.

An isolated left $\mathrm{i} / 2$ associated with the mandible (MNCN 08.17.10904a; Fig. 6) shows a prominent lingual cristid.

MNCN 08.17.9702 is a deeply worn right I1/ (Fig. 6). It retains only a small portion of enamel on the labial surface.

Tooth wear. The teeth of the Carpetana tetraconodont are all heavily worn, the occlusal surfaces showing numerous scratches visible even under low magnification (4x). Wear is especially heavy on the upper and lower incisors and the molars, but the posterior premolars also show large dentine lakes surrounded by wrinkled enamel (Fig. 7). The roots of the $\mathrm{p} / 3$ and $\mathrm{p} / 4$ are stout, and are as large as, or larger than, the roots which support the molars.
The heavy wear on the incisors indicates either that they were used extensively in food gathering and perhaps in initial processing of the food items, or that the food was covered in an abrasive matter such as sandy soil or protected by a durable shell such as nuts. The stoutness of the roots of the posterior premolars, their pointed apices, and thick, wrinkled enamel, indicate that these teeth were employed for breaking food items, perhaps cracking nuts, for example. The wear on the molars is so extensive that whatever was being masticated by them probably contained abrasive or durable contents such as fragments of nut shells, or grains of sand. The necessity for further study of tooth wear in Conohyus is clearly indicated by these observations.

Remarks. The tetraconodont lower jaws from Carpetana are of great significance because they provide an association between the incisors, canines, premolars 


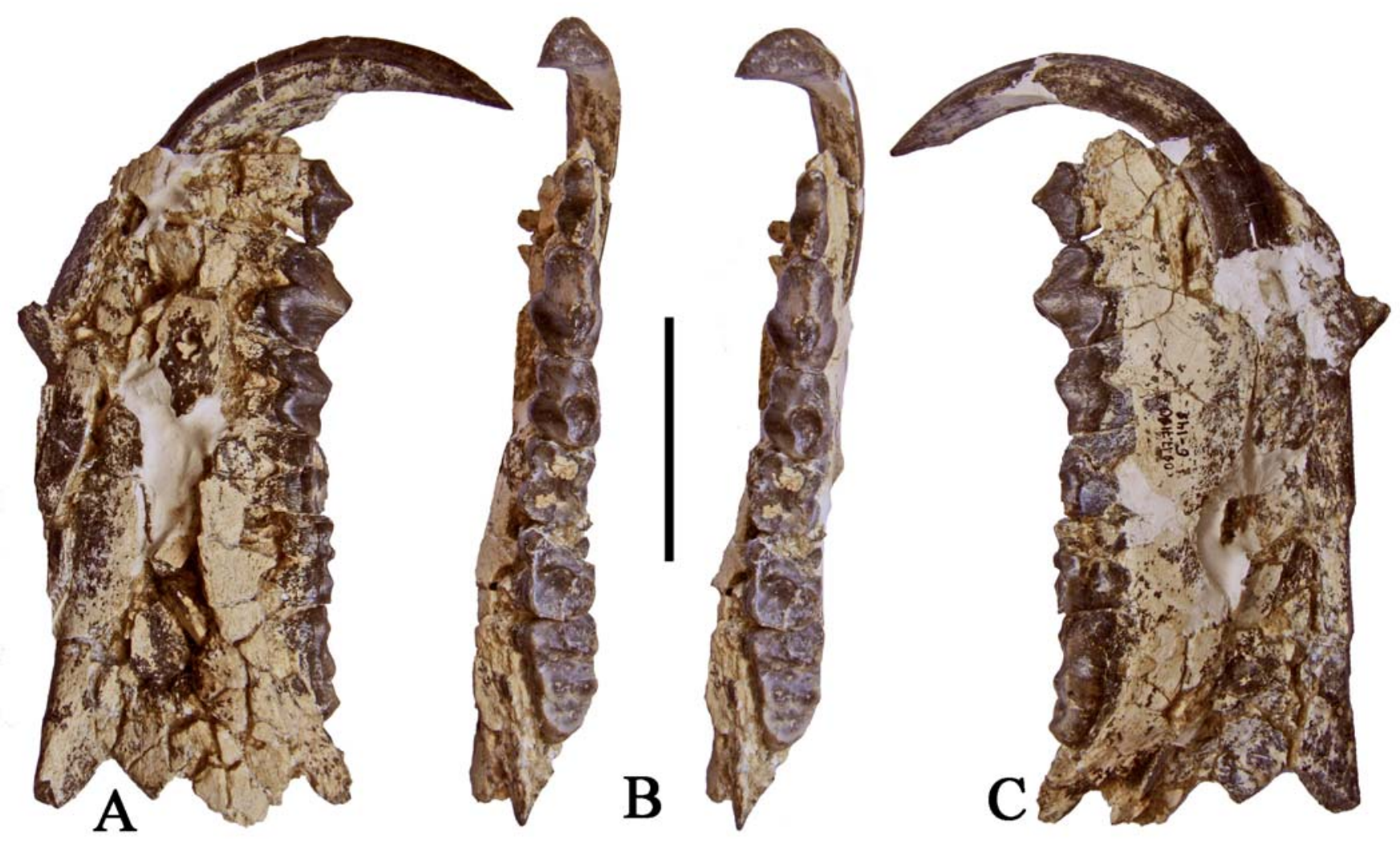

Figure 3. Conohyus simorrensis from Carpetana (MN 6), Madrid. MNCN 08.17.7180 left mandible containing c/m, p/2-m/3. A) buccal, B) stereo occlusal, and C) lingual views (scale: $5 \mathrm{~cm}$ ).

and molars, the only tooth not in situ being the $\mathrm{i} / 3$. The tetraconodont fossils available from most localities do not preserve this association, the only other localities known to do so are Göriach, Austria (Hofmann, 1893), Steinheim, Germany (Fraas, 1870; Chen, 1984), and Lucane, Croatia (Bernor et al., 2004).

Comparison by the author with other European tetraconodont samples indicates that the morphology of the Carpetana fossils agrees closely with the lectotype of Conohyus simorrensis from Villefranche d'Astarac, France (Pickford \& Laurent, in press). The $\mathrm{m} / 3 \mathrm{~s}$ from Carpetana are slightly shorter than the French sample, but are bigger than the Göriach assemblage (Hofmann, 1893) classified as Conohyus simorrensis goeriachensis by Van der Made (1989).

The Carpetana $p / 2$ is moderately trenchant with a pointed main cusp, and the tooth is not vertically offset in the jaw with respect to the $\mathrm{p} / 3$. In these features it is similar to the lectotype of Conohyus simorrensis, but differs from other $\mathrm{p} / 2 \mathrm{~s}$ from Villefranche d'Astarac and Göriach, which are more bunodont and which have better developed bucco-distal swellings than the Carpetana fossils, and which show a clear vertical offset between the level of the $p / 2$ and the $p / 3$.
Morphometric comparisons. The Carpetana fossils agree closely in dimensions of the $\mathrm{p} / 2-\mathrm{p} / 4$ and $\mathrm{m} / 3$ with specimens of Conohyus simorrensis and Conohyus goeriachensis from Villefranche d'Astarac measured by the author (Fig. 8) but differ markedly from the Steinheim species Conohyus steinheimensis. The features that distinguish the two tetraconodont species from Villefranche d'Astarac include the morphology of the anterior premolars; more bunodont in $C$. goeriachensis and vertically offset in the jaws relative to the $p / 3$, and more sectorial in C. simorrensis, and set in the jaw at the same level as the $\mathrm{p} / 3$. There are also differences in the talonid of the $\mathrm{m} / 3$ and the orientation of the distal root; more buccally inclined in $C$. simorrensis than in $C$. goeriachensis.

\section{DISCUSSION}

The Carpetana tetraconodont fossils are confidently attributed to Conohyus simorrensis (Lartet, 1851). The recent rediscovery of the long "lost" fossils of Sus simorrensis Lartet (1851) has enabled the nomination of a lectotype (Pickford \& Laurent, in press), which is morphometrically close to the specimens from Carpetana with the minor exception that the $\mathrm{m} / 3$ from Villefranche 

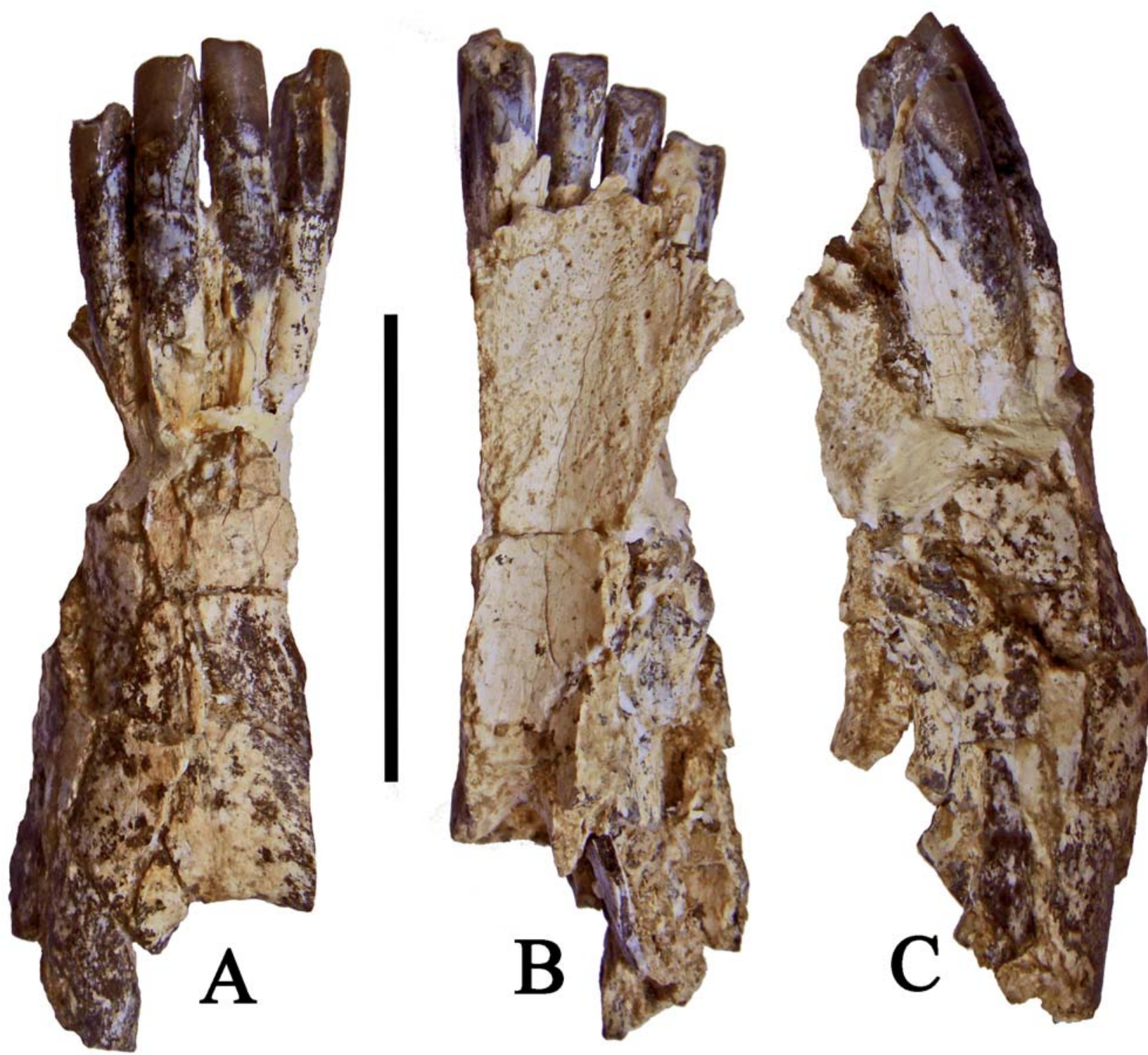

Figure 4. Conohyus simorrensis from Carpetana (MN 6), Madrid. MNCN 08.17.7180 symphysis of the mandible containing left and right $\mathrm{i} / 1-\mathrm{i} / 2$ and part of the right canine. A) ventral, B) dorsal, and C) right lateral views (scale: $5 \mathrm{~cm}$ ).

d'Astarac is slightly larger than the specimens from Carpetana.

Comparison of Conohyus simorrensis from Carpetana with other tetraconodont assemblages from Europe, indicate that it is larger than the Göriach association classified as the subspecies Conohyus simorrensis goeriachensis by Van der Made (1989). Its slightly trenchant anterior premolars differ from the more bunodont Göriach specimens, and the anterior premolars are not vertically offset in the jaw like those at Göriach, in which the $\mathrm{p} / 2$ and $\mathrm{p} / 1$ crowns are positioned below the level of the cervix of the $\mathrm{p} / 3$.

The Carpetana tetraconodont differs in several features from Conohyus steinheimensis, not only metrically (the Steinheim fossils are smaller than the Carpetana ones) but also in the morphology of the anterior premolars, which at Steinheim are more bunodont and are adorned with a bucco-distal swelling with enamel folds. There are also differences between the proportions of the premolars relative to each other and to the molars. The Steinheim $\mathrm{p} / 3 \mathrm{~s}$, for example are smaller relative to the $\mathrm{p} / 4$ than they are in the Carpetana suids, in which the $\mathrm{p} / 3$ is bigger than the $\mathrm{p} / 4$.

The Carpetana suid is larger than Conohyus huenermanni Heissig, 1979, from Breitenbrunn, Germany, and Conohyus olujici from Lucane, Croatia (Bernor et al., 2004), which are likely to be synonyms, and both probably belong to Parachleuastochoerus in the basis of dimensions and dental morphology. In addition there are morphological 


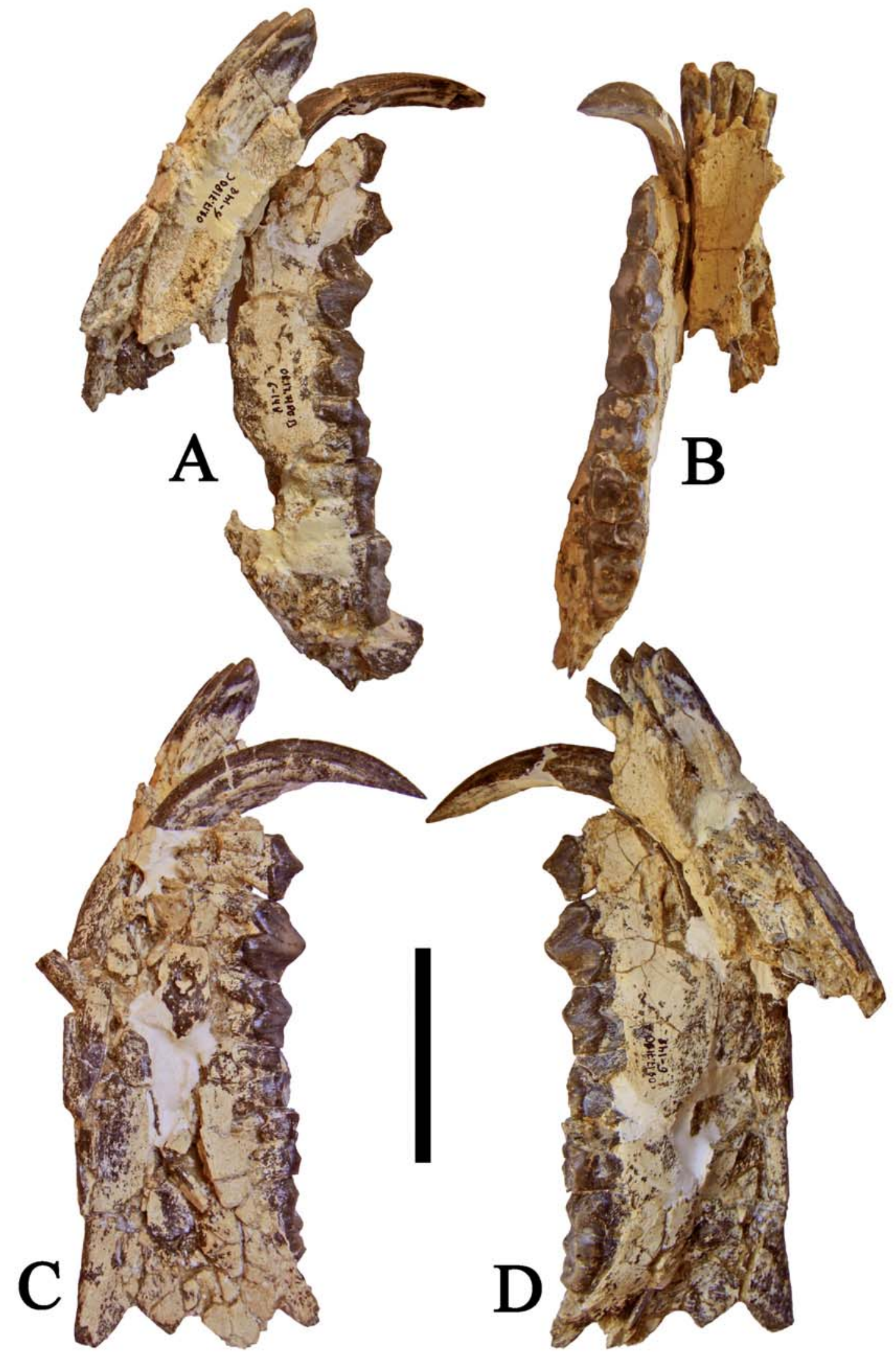

Figure 5. Conohyus simorrensis from Carpetana (MN 6), Madrid. MNCN 08.17.7180 right mandible containing p/1-m/3. A) right mandible articulated with the symphysis and right canine apex, lingual view, B) occlusal view of left mandible articulated with the symphysis, C) lateral view of the left mandible articulated with the symphysis, and D) lingual view of the left mandible articulated with the symphysis (scale: $5 \mathrm{~cm}$ ). 


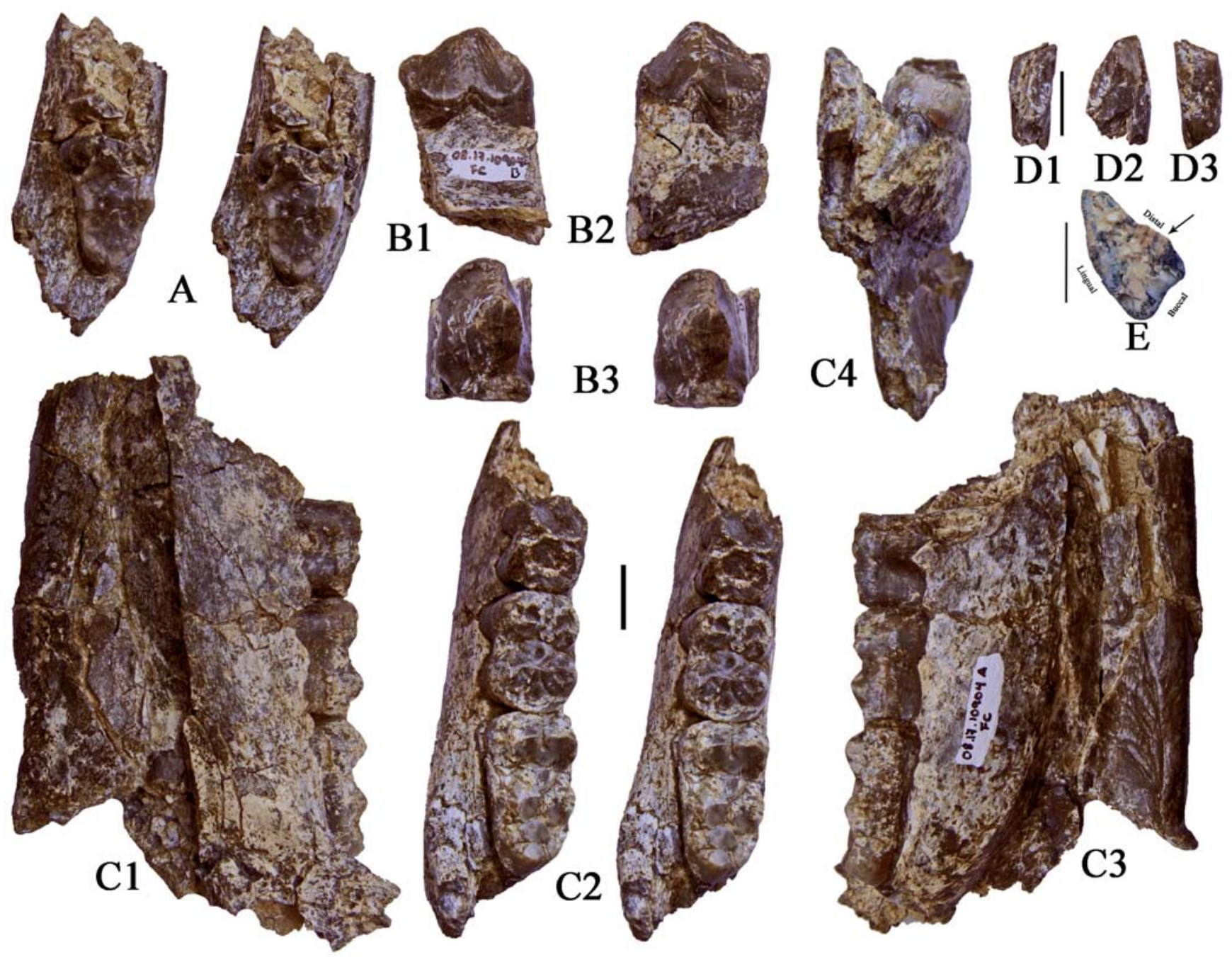

Figure 6. Conohyus simorrensis from Carpetana (MN 6), Madrid. A) left mandible containing damaged m/2-m/3, stereo occlusal view, B) MNCN 08.17. 10904b, left p/3, B1: lingual, B2: buccal and B3: stereo occlusal views, C) MNCN 08.17.10904a, left mandible containing m/1-m/3, C1: buccal, C2: stereo occlusal, and C3: lingual view, C4: distal view to show slight buccal tilt of the distal root of $\mathrm{m} / 3$ and the deep sub-lingual fossa, D) left i/2, D1: lingual, D2: lateral and D3: labial views, and $\mathbf{E}$ ) scrofic section of canine, showing the ridge of cementum (arrow) (scales: $10 \mathrm{~mm}$ ).

differences in anterior premolars and the vertical offset on the alveolar process that supports them which makes it unlikely that they belong to the same genus. The Lucane mandibles show an almost vertically oriented distal root in the $\mathrm{m} / 3$, unlike the slightly buccally tilted root in the Carpetana fossils. In the Steinheim suid the distal root of $\mathrm{m} / 3$ is markedly tilted buccally.

The Carpetana suid shares some morphological features with Parachleuastochoerus, such as the sectorial morphology of the anterior premolars, which have a pointed apex. It is appreciably larger than Parachleuastochoerus crusafonti (Golpe-Posse, 1972; Pickford, 1981) and Parachleuastochoerus kretzoii Fortelius et al. (2005). However a close relation between Conohyus simorrensis and Parachleuastochoerus species can be excluded on the basis of divergent premolar proportions. For instance, the $\mathrm{p} / 3$ of Parachleuastochoerus species is significantly narrower relative to the breadth of the $\mathrm{p} / 4$ and that of the $\mathrm{m} / 3$ than it is in Conohyus simorrensis, in which the $\mathrm{p} / 3$ is as broad as the $\mathrm{p} / 4$ and the $\mathrm{m} / 3$ (Fig. 8).

Conohyus simorrensis from Carpetana is compatible in dimensions with nov. gen. (ex- "Propotamochoerus") salinus (Pilgrim, 1926) which is closely related to Hyotherium pilgrimi Pickford (1988) and Parachleuastochoerus sinensis Pickford \& Liu (2001). However, it is difficult to evaluate the relationships between these suids because the main differences between them reside in the skull, which is poorly represented for all the species save "Propotamochoerus" salinus, for which the only known cranial material is crushed However, the differences in 

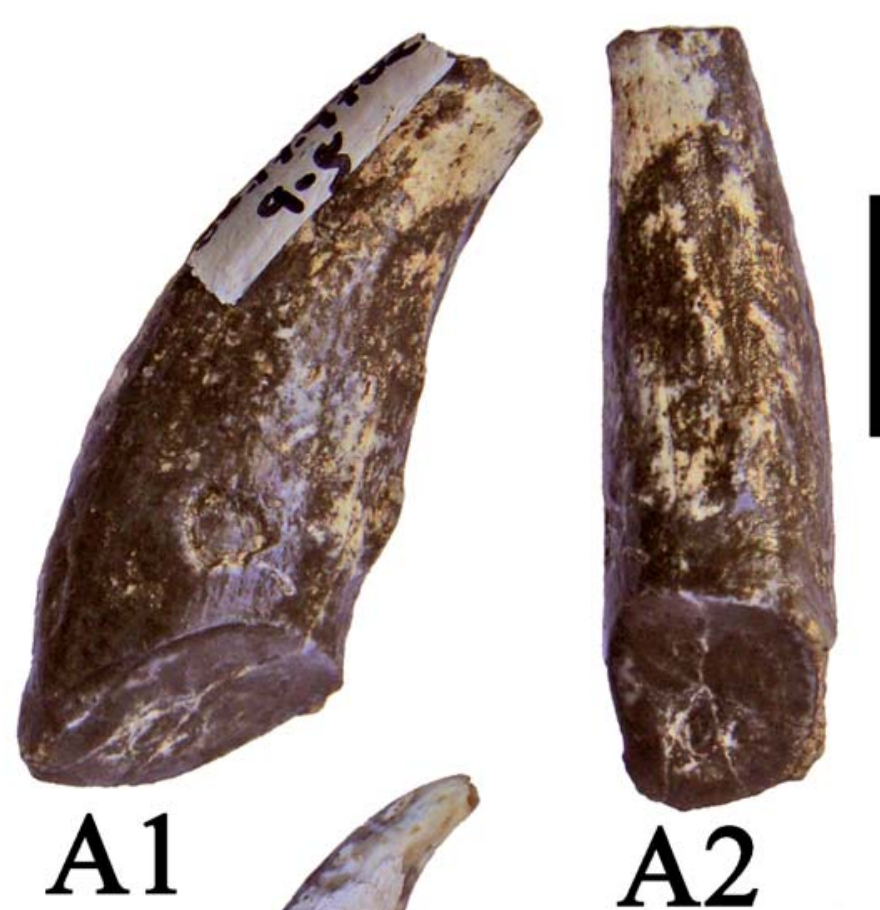

A1

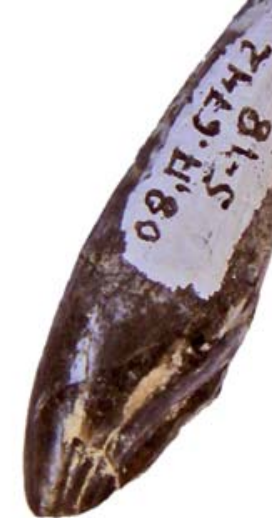

B1

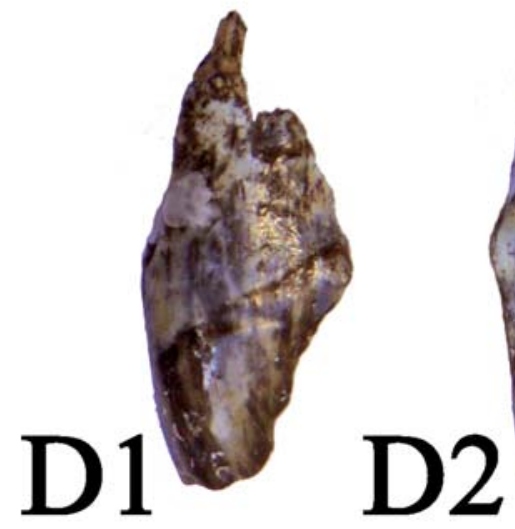

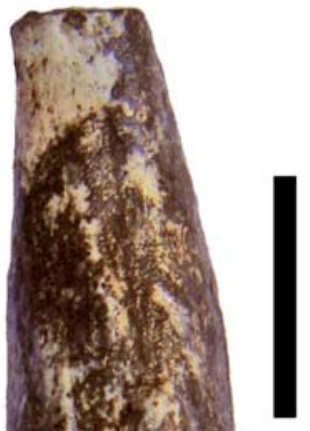
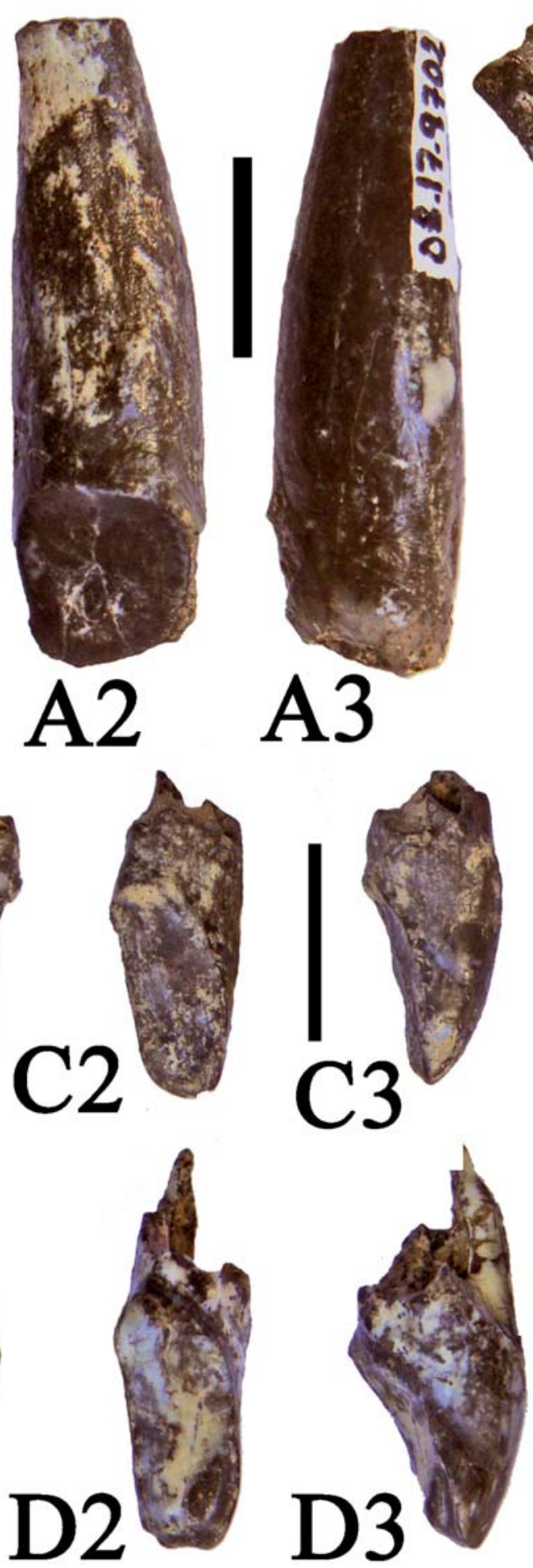

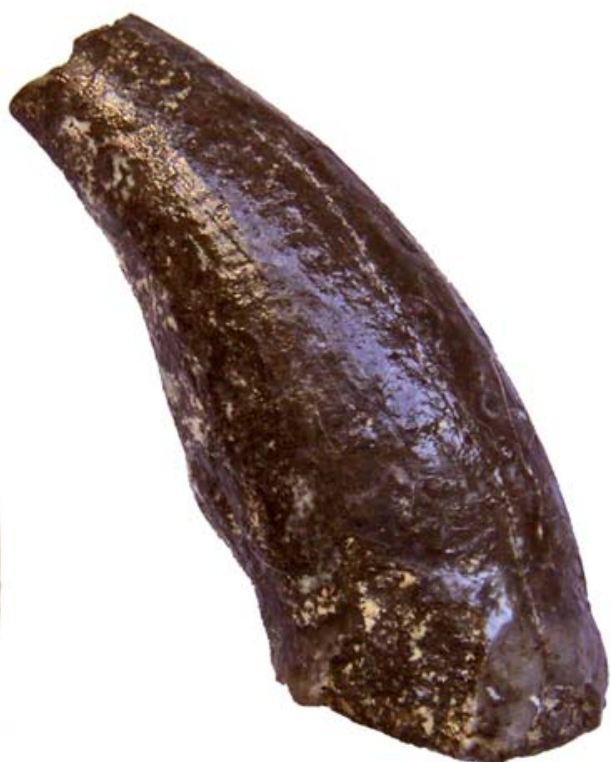

A4

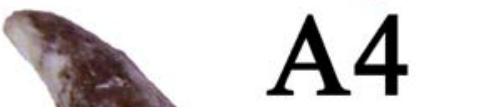

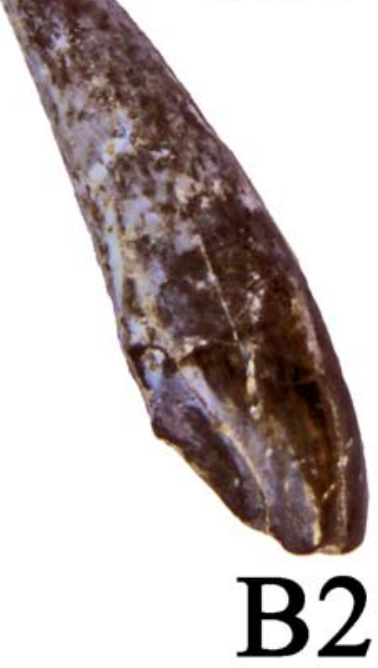

B2

Figure 7. Upper incisors of Conohyus simorrensis from Carpetana (MN 6), Madrid. A) MNCN 08.17.9702.9-5, heavily worn right I1/, A1: mesial, A2: lingual, A3: labial, A4: distal views, B) MNCN 08.7.6742, left I2/, B1: distal, B2: lingual views, C) MNCN 08.17, left DI1/, C1: mesial, C2: lingual and C3: distal views, D) MNCN 08.17, left I3/, D1: distal, D2: lingual and D3: mesial views (scale: $10 \mathrm{~mm}$ ). 


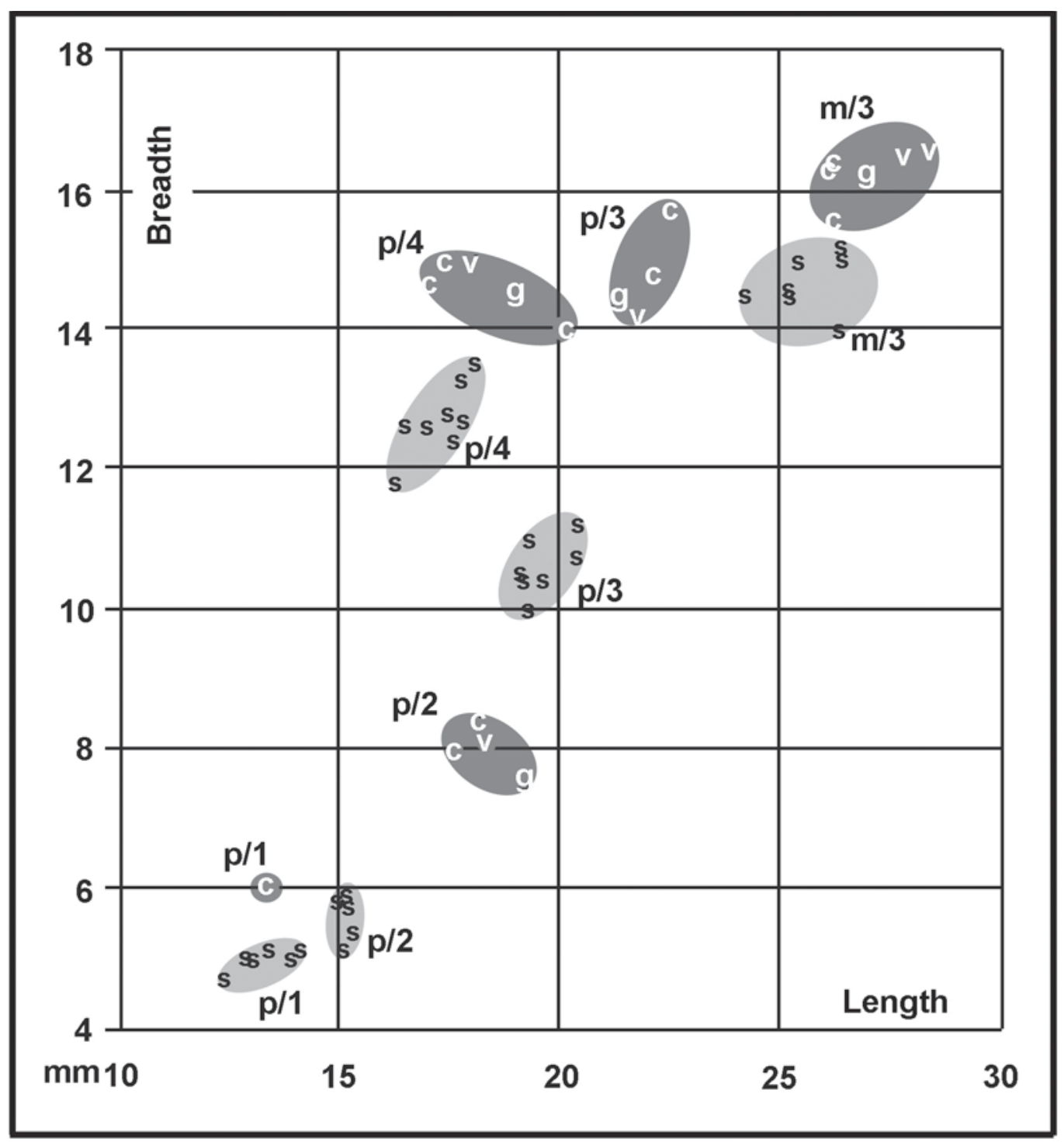

Figure 8. Bivariate plot of the premolars and $\mathrm{m} / 3$ of Conohyus simorrensis from Villefranche d'Astarac (the lectotype "v") and Carpetana ("c") with Conohyus goeriachensis from Villefranche d'Astarac ("g") and Conohyus steinheimensis from Steinheim ("s") (all measurements are by the author).

the proportions of the premolars relative to each other and to the molars exclude the possibility of a particularly close relationship between the Carpetana suid and "Propotamochoerus" salinus.

The Carpetana fossil suid is appreciably smaller than material from Fonte do Pinheiro, Portugal, attributed to Conohyus simorrensis doati by Roman (1907) and specimens from El Buste and La Ciesma, Spain, identified as Conohyus ebroensis Azanza (1986). This large tetraconodont species could however belong to the same genus as the Carpetana fossils, as the $\mathrm{p} / 2$ in the Fonte do Pinheiro specimen is not offset in the mandible and it is reported to have a sectorial crown (Roman, 1907). There are also dental resemblances to the large North African "Propotamochoerus" devauxi Arambourg, 1968, which is a tetraconodont and not a suine (Cooke, 1982).

\section{CONCLUSION}

The tetraconodont suid specimens, from Carpetana, Madrid, Spain (MN 6), are attributed to Conohyus simorrensis on the basis of close morphometric similarities to the lectoype material from Villefranche d'Astarac, France (Pickford \& Laurent, in press). Because of their relatively complete preservation, the Carpetana fossils throw a great deal of light on the species, which was hitherto poorly understood.

\section{ACKNOWLEDGEMENTS}

Thanks to Jorge Morales for making the Carpetana fossils available for study. 


\section{REFERENCES}

Arambourg, C. 1968. Un Suidé fossile nouveau du Miocène supérieur de l'Afrique du Nord. Bulletin de la Société géologique de France, Séries 7, 10, 110-115.

Azanza, B. 1986. Estudio geologico y paleontologico del Mioceno del sector oeste de la Comarca de Borja. Cuadernos de Estudios Borjanos, 7-8, 63-126.

Bernor, R., Bi, S. \& Radovcic, J. 2004. A contribution to the evolutionary biology of Conohyus olujici n. sp. (Mammalia, Suidae, Tetraconodontinae) from the early Miocene of Lucane, Croatia. Geodiversitas, 26, 509-534.

Chen, G. 1984. Suidae and Tayassuidae (Artiodactyla, Mammalia) from the Miocene of Steinheim a. A. (Germany). Palaeontographica, 184(1-4), 79-83.

Cooke, H.B.S., 1982. A preliminary appraisal of fossil Suidae from Sahabi, Libya. Garyounis Scientific Bulletin, 1982, 71-82.

Fortelius, M., Amour-Chelu, M., Bernor, R. \& Fessaha, N. 2005. Systematics and Palaeobiology of the Rudabanya Suidae. Palaeontographic Italica, 90, 259-282.

Fortelius, M., van der Made, J. \& Bernor, R.L. 1996. Middle and Late Miocene Suoidea of Central Europe and the Eastern Mediterranean: Evolution, Biogeography and Palaeoecology. In: The Evolution of Western Eurasian Neogene Mammal Faunas, (eds. Bernor, R.L., Fahlbusch, V. \& Mittmann, H.-W.). Columbia University Press, New York, 348-379.

Fraas, O. 1870. Beiträge zur Fauna von Steinheim. Mit Rüchsicht auf die miocenen Säugetier. und vogelreste des Steinheimer Beckens. Jahreshefte der Vereinigung Vaterländische Naturkunde Würtembergs, 26, 145-306.

Golpe-Posse, J.M. 1972. Suiformes del Tertiario Español y sus yacimientos. Paleontología y Evolución, 2, 1-198.

Gray, J.E. 1821. On the natural arrangement of vertebrose animals. London Medical Repository, 15(1), 296-310.

Heissig, K. 1989. Conohyus huenermanni n. sp., eine kleine Schweineart aus der Oberen Süsswassermolasse Bayerns. Mitteilung der Bayerische Staatssammlung für Paläontologie und historische Geologie, 29, 235-240.

Hofmann, A. 1893. Die Fauna von Göriach. Abhandlungen der k.k. geologische Reischsanstalt, 15, 1-87.

Hünermann, K.A. 1968. Die Suidae (Mammalia, Artiodactyla) aus den Dinotheriensanden (Unterpliozän = Pont) Rheinhessens (Südwestdeutschland). Schweizerische Paläontologische Abhandlungen, 86, 1-96.

Hünermann, K.A. 1999. Family Suoidea. In: The Miocene Land Mammals of Europe,(eds. Rössner, G.E. \& Heissig, K). Verlag, München, 209-216.

Kaup, J.J. 1859. Beiträge zur näheren Kenntnis der urweltlichen Säugethiere, Volume 4, 1-31, Darmstadt.
Lartet, E. 1851. Notice sur la Colline de Sansan, suivi d'une récapitulation des diverses espèces d'animaux vertébrés fossiles, trouvés soit à Sansan, soit dans d'autres gisements du terrain tertiaire miocène dans le bassin sous-pyrénéen. J-A Portes, Auch.

Lydekker, R. 1876. Fossil mammalian faunae of India and Burma. Records of the Geological Survey of India, 9, 86-106.

Pickford, M. 1981. Parachleuastochoerus (Mammalia, Suidae). Estudios Geologicos, 37, 313-320.

Pickford, M. 1988. Revision of the Miocene Suidae of the Indian Subcontinent. Münchner Geowissenschaftliche Abhandlungen, 12, 1-91.

Pickford, M. \& Laurent, Y., in press. Valorisation of palaeontological collections: nomination of a lectotype for Conohyus simorrensis (Lartet, 1851), Villefranche d'Astarac, France. Estudios Geológicos.

Pickford, M. \& Liu L. 2001. Revision of the Miocene Suidae of Xiaolongtan (Kaiyuan), China. Bollettina della Società Paleontoloogioca Italiana, 40, 275-283.

Pickford, M. \& Morales, J. 2003. New Listriodontinae (Mammalia, Suidae) from Europe and a review of listriodont evolution, biostratigraphy and biogeography. Geodiversitas, 25, 347-404.

Pilgrim, G.E. 1925. Presidential address to the Geological Section of the $12^{\text {th }}$ Indian Science Congress. Proceedings of the $12^{\text {th }}$ Indian Scientific Congress, p. 200-218.

Pilgrim, G.E. 1926. The Fossil Suidae of India. Memoir of the Geological Survey of India, Palaeontologica indica, 8(4), 1-65.

Roman, F. 1907. Le Néogène continental dans le Basse Vallée du Tage (Rive droite). Commission du Service Géologique de Portugal, Lisbonne, 1907, 1-78.

Stehlin, H.G. 1899-1900. Über die Geschichte des Suiden Gebisses. Abhandlungen der Schweizerischen Paläontologischen Gesellschaft, Zürich, 26/27, 1-527.

Van der Made, J. 1989. A Conohyus lineage (Suidae, Artiodactyla) from the Miocene of Europe. Revista Española de Paleontología, 4, 19-28.

Van der Made, J. 1998. Biometrical trends in the Tetraconodontinae, a subfamily of pigs. Transactions of the Royal Society of Edinburgh: Earth Sciences, 89, 199-225.

Van der Made, J. \& Morales, J. 2003. The pig Conohyus simorrensis from the Upper Aragonian of Alhambra, Madrid, and a review of the distribution of European Conohyus. Estudios Geológicos, 59, 303-312.

Van der Made, J., \& Salesa, M., 2004. Early remains of the pig Conohyus simorrensis from the Middle Aragonian of Somosaguas near Madrid - its dispersal into Europe and evolution. Neues Jahrbuch für Geologie und Paläontologie Abhandlungen, 233, 153-168. 